\title{
The R(Evolution) of Territorial Marketing : Towards an Identity Marketing
}

\author{
Yasmine ALAOUI and Rihab ABBA
}

ESCA École de Management, Casablanca, Maroc

Correspondence should be addressed to: Rihab ABBA; rabba@esca.ma

Received date: 3 May 2018; Accepted date: 19 December 2019; Published date: 24 April 2019

Academic Editor: Lotfi Gammoudi

Copyright (C) 2019. Yasmine ALAOUI and Rihab ABBA . Distributed under Creative Commons CC-BY 4.0

\begin{abstract}
In a context of asserted competition, political decision-makers in charge of territorial destiny can no longer resolve to "do things well", they must 'do the right things", those that will be the most structuring and the most determining for the future of the territory. They now have to face new dilemmas and tensions which force them into showing more discernment, responsiveness as well as creativity to address the growing complexity of local issues. They must retain the territorial marketing that will not only allow their territory to develop, but first of all to survive. As a result, territorial marketing today takes a broader, more in-depth, more strategic and more versatile approach, drawing on sources as diverse as anthropology, sociology, culture, etc. Identity marketing is part of the new practices of territorial marketing and draws from the reservoir of the territory's intrinsic strengths and weaknesses to develop its territorial marketing approach. This paper has two main objectives; the first one is to explore and present the major new marketing practices, the result of observations at the level of several territories - Some of these practices have already been formalized and have proven their worth in terms of outcomes; others have reached in the improvement phase or are going through the experimental stage. The second objective of this article is to explain the state of mind of the new identity-based territorial marketing approach that will allow territories to be branded in order to be noticed.
\end{abstract}

Keywords: Territorial marketing, new practices, identity, identity marketing

\section{Résumé}

Dans un contexte de concurrence affirmée, les décideurs politiques, responsables de la destinée territoriale, ne peuvent plus se résoudre à "bien faire les choses », ils doivent faire "les bonnes choses », celles qui seront les plus structurantes et les plus prégnantes pour l'avenir de leur territoire. Désormais, face à de nouveaux dilemmes et

Cite this Article as: Yasmine ALAOUI and Rihab ABBA (2019), "The R (Evolution) of Territorial Marketing: Towards an Identity Marketing “, Journal of Marketing Research and Case Studies, Vol. 2019 (2019), Article ID 944163, DOI: 10.5171/2019.944163 
tensions, ils doivent faire preuve de discernement, de réactivité mais aussi de créativité devant la complexité grandissante des enjeux locaux. Ils se doivent de retenir les stratégies du marketing territorial d'abord susceptibles de permettre à leur territoire de se développer, mais surtout qui en assureront la survie. De ce fait, le marketing territorial prend aujourd'hui une dimension plus ample et plus approfondie, plus stratégique et plus polyvalente, glanant dans des sources aussi diverses que l'anthropologie, la sociologie ou la culture. Le marketing identitaire est ainsi une nouvelle pratique du marketing territorial consistant à puiser dans le réservoir des atouts et des faiblesses intrinsèques au territoire pour élaborer sa démarche marketing territorial.

Ce papier a deux objectifs majeurs; le premier est d'explorer et de présenter l'essentiel des nouvelles pratiques du marketing territorial, fruit des observations au niveau de plusieurs territoires - certaines de ces pratiques sont déjà formalisées et ont fait leur preuve en termes de résultats, d'autres sont en phase d'amélioration ou en stade d'expérimentation-. Le deuxième étant d'expliciter l'état d'esprit de la nouvelle démarche du marketing territorial basé sur l'identité qui permettrait aux territoires d'être marqués pour être remarqués.

Mots clés : Marketing territorial, nouvelles pratiques, identité, marketing identitaire.

\section{Introduction}

Territorial marketing is far from being a $21^{\text {st }}$ century invention. The idea that a territory has to look for notoriety and attract targets is not original in itself (Meyronin, 2009) and some practices go back as far as the $19^{\text {th }}$ century. According to the historicist Stephen Ward who based his views on Alexandre Basdereff's works, "public marketing" has an essential advantage as it puts together the private sector's efficiency along with the concern of general interest. He supports the idea that the elaboration of a marketing plan could help solve two issues that far outweigh mere communication: finding solutions to the needs of users and promoting local economic activity.

This marketing approach models on the one applied by companies although with major nuances. It is divided into three phases: First the marketing study of the territory's environment, then the elaboration of strategic marketing specifically focused on segmentation, targeting and positioning, and finally implementing operational marketing, the objective of which is to adopt a targeted offer.

One of the nodal points of this approach is to convey the political will of elected representatives and bodies responsible of territorial marketing and appeal strategy to assert and/or reinvent the territorial identity. Consequently, practitioners and researchers gradually become aware of the importance of the identitarian dimension in the territorial marketing approach.

In this vein, many researchers, namely Rochette (2015), Alaux (2015), Gayet (2015) and Chamard (2014) perceive identity as the founding nucleus around which strategy; governance, offer, brand, brand image and territorial communication are built. However, it should be mentioned that this identity is not fixed. On the contrary, it unites past, present and future visions; it is moving and constantly changing.

In this respect, our research will clarify the new practices of territorial marketing (holistic marketing, shared marketing, citizen-based marketing, hypersegmentation marketing, excellence marketing, creative marketing, digital marketing, customization marketing, viral marketing, experience marketing). We will highlight the central component of this emerging territorial marketing which advocates identity as a pillar concept (identity marketing), thus forming a solid base for the territory values, likely to federate all stakeholders and develop a strong and sustainable territorial brand in order to conceive a relevant offer for citizens (who could then act as ambassadors) as well as for the tourists 
and investors that the territory aims to attract.

\section{Overview on the 10 New Practices of Territorial Marketing}

\section{A Marketing Based On a Holistic Approach}

This first approach is a vision that tackles all functions and aspects of territorial marketing: its strategy, financing, positioning brand, etc. Gayet (2014) develops six methods to apprehend the holistic approach, or what he calls "integrated marketing". We will present hereunder an overview of these methods and the territories where the related mindset has been mobilised:

- Integrating the approach within the territory's project: this is what Barcelona chose to apply when implementing its project "Barcelona Vision 2020", as it was the general territory project that oriented the decision-makers towards territorial marketing;

- Integrating the approach into the pattern of operational development; that was the choice of Saint-Etienne, "80 actions to boost Stephanoise attractiveness" (Maynardier, 2011). In this sense, what matters most is the concept of city. This vision focuses on the project, which includes even the strategy of attractiveness as one of its components. As far as the region of Bretagne has considered it, this method is perceived as innovative and specific.

- Developing a strategy based on four general orientations that translate into a series of twenty priority actions: that method was the choice of Alsace region. It takes the shape of a logical flow from the strategic dimension to the operational one. "Amsterdam Marketing" has followed the same path and segmented its market in seven target groups for which the managers have defined specific priority actions. These comprehensive dynamics allow the intensification of verticality and the readability of the action.

- Developing a territorial brand that acts as an atrium and around which the stakeholders cooperate and contribute to the development of a transversal approach: this is the method that Lyon, Colorado and Michigan have opted for.

- Emergence of a willingness to tune marketing coordination with a function of conductor, whose primary mission is to optimize harmony between actions or tools, and/or to mutualize techniques and operations: that is what Berlin and Brussels have chosen to do.

- Developing a marketing strategy based on a big event or a major facility that federates the entirety of stakeholders and actors in the project. That is the case of London (Olympic Games), Marseilles (European Capital of Culture) and Brazil (Football World Cup).

These six practices confirm that marketing puts into motion various dynamics and intentions that share the same goal: territorial attractiveness.

\section{A Shared Marketing}

Among the strong lines of this movement, we can list the relevance of the territory, its nature, its functions, its dimensions and the identification of its potential actors. The main idea is the required synergy between actors as well as a sector porosity that allows the optimization and mutualisation of resources.

The researchers Winker and Seigis (2012), cited by Eshuis, Klinj and Braun (2014), support the idea that territorial marketing can play a central role in the process of organization and dialogue with stakeholders.

Chamard (2014), for his part, supports that animating a network of stakeholders is a vital stake for territorial marketing. Boris heads in the same direction by confirming that stakeholders can only adhere with the values they have taken part in formulating. 
In this vein, the inhabitants have a great part of responsibility. As to identity, it is the keystone of these shared values.

\section{A More and More Citizen-Based Marketing}

Citizens have started manifesting their willingness to take part in the development of their territory. In this regard, according to Eshuis and Klijn (2013), several debates about participation of citizens have emerged. These researchers have worked on the criticisms directed at territorial marketing practitioners and have brought out the most recurrent criticism, that marketing followed a "top-down" approach, which means that decisionmakers had the prerogative to develop a strategy and implement it without taking into account the needs and desires of the citizens.

Residents today are more involved in attractiveness and territorial marketing strategies, thanks to meetings as well as consultations via Internet (Gayet, 2015). Elected representatives, territorial marketing practitioners, strategists and technicians are now aware of the importance of involving citizens in the process of territorial marketing. According to Klijn \& Braunn (2014), territorial marketing doesn't aim at satisfying the needs of tourists and external investors alone, but also and above all the inhabitants of the region. Thus, residents are both participants and recipients. The borderline between endogenous and exogenous targets gets blurrier, and the involvement of residents becomes inescapable since they act as first ambassadors of their territory (Meyronin, 2014). Maynardier sharpens the study and confirms that this method of governance "allows the creation of figures, of partners, of colleges, of ambassadors", a necessary involvement both for the project's identification and for its recognition.

The region of Alsace has worked on its identity and its territorial attractiveness approach with more than 4200 residents, thanks to a blog and to social media.

\section{A Marketing Based On Hyper- Segmentation}

The territorial offer is more and more segmented, even hyper-segmented, which Chamard (2015) describes as affinitybased or communitarian, on the fact that the territory pools individuals according to "affinity".

Gayet (2015) hones the idea by adding that each community works as a separate tribe, with its own language, codes, tools and networks. For Amidou (2014), this community is built around three main elements: the individuals, the links and the shared contents. Thus, the larger rallying models being no longer relevant, addressing customers in a more precise, adapted and affinity-based way, would give better results. Consequently, one example of hyper-segmentation would be to break down a touristic offer, for instance, in romantic weekends, tours for single people, stays for families, bachelors events etc.

Tourism in Alsace region is another salient example, as this touristic vision motivates more than one million and half visitors, with a confirmed potential of more than two hundred million (Chamard, 2015). As a matter of fact, tourism in Alsace has developed affinity-based themes rallying a great number of people, and has leveraged around labels such as "Christmas in Alsace", "The Road of Alsace Wines", etc.

Gayet (2016) adds that with the intensification of social media use, each member becomes multifunctional: commentator, inspirer, purchaser, developer, controller, seller or diffuser. As such, the individual intervenes in the process of services quality while playing a major role in developing customer surveillance and improving the territorial offer.

\section{A Marketing that has a motto: excellence}

In this new context characterized by the customer's opportunism and exigency, excellence is no longer a choice; it has become a sales factor (Gayet, 2015). 
The study of the new trends and practices of territorial marketing confirms that the most attractive territories are the ones that have succeeded in their territorial marketing approach by relying on excellence.

Along with the proposal of effective methods and solutions, excellence requires to dare think differently, to break with the existing situation and to advocate innovation. In order to reach excellence, it is recommended to develop the related competencies so as to showcase the virtues of "differentiation" (Rochette, 2012); a key element in the improvement of the territory's attractiveness.

Chamard (2015) points out that when territories favour this approach, excellence is also to be found in other associated fields such as clusters, governance, labels, sustainability, innovation, etc. Gayet adds to this list the following items: effective ecosystems, collaborative economy, territorial brand, smart city and real-time customer relationship management.

\section{A Creative Marketing}

As far as territorial marketing is concerned, we choose to use the definition of creativity suggested by Garcia and Peganow (2012), according to whom creativity is "the capacity to produce new and adapted ideas". Except that creativity in public domain doesn't emerge spontaneously, it is managed and supervised.

For Garcia and Peganow (2012), creativity rests on three pillars:

- The climate: it refers to an atmosphere of trust-building and autonomy;

- The competencies: both individual and collective;

- The processes: a central component that ensures and fosters participation of as many people as possible.

The objective is to help this creativity develop in organizations and become an integrated approach to their functioning.
Gayet indicates that innovation and creativity are essential at all levels of the territorial marketing approach: from shared diagnosis to influence strategy, through identity studies, governance and attractiveness. It is also based on the creation of citizen-friendly platforms such as crowd-funding, crowdsourcing, customized communication, etc. Amidou (2014) completes the idea and alerts to the fact that innovation is a mandatory survival mode in a permanently moving and accelerating environment.

In practice, UNESCO created in 2004 a network dedicated to creative cities that aims at forming a union to help exploit creative, social and economic potential in local communities and promote them. Each year, UNESCO organizes a meeting with several objectives: First to go over the initiatives taken in order to integrate creativity to a sustainable urban development, then to establish partnerships and think about future development and strategic goals for a geographically balanced enlarged network, third to establish selection criteria of host cities for the next annual meetings and to periodically revise affiliations to the network.

Other researchers go even further by claiming that marketing doesn't hold a meaning if it is not different. Villemus (2014) considers that the phrase "different marketing" in itself is a pleonasm, since marketing is different by definition.

\section{A Marketing More Digital Than Ever}

Digital marketing refers to the Internetbased marketing methods and tools: online communication (social media influence), optimization of e-commerce, creation of traffic through digital devices (computer, mobile phone, podcast reader, video games, dynamic display - external advertising boards and television in selling points).

Digital marketing is essential to the existence of Generation Y. For Villemus (2014), the generation of digital boomers born after 1995 doesn't live "with" the Internet but "within" the Internet, now becoming a world in itself. This leads to the

Yasmine ALAOUI and Rihab ABBA (2019), Journal of Marketing Research and Case Studies,

DOI: $10.5171 / 2019.944163$ 
oxymoron "virtual reality", in which an individual turns into a "He/She" before being an "I" (Cohen, 2012). This marketing optimizes traditional/regular marketing and can even replace it.

It is obvious that nowadays, digital marketing allows doing what was thought impossible to achieve with marketing 1.0 and imposes itself as a multifunctional and multidimensional way. It is definitely thanks to this latter that it has become possible to develop a collaborative economy, an affinity-based marketing (4.4), a real-time marketing (Gayet, 2014) and a policy of ambassadors for territorial brands.

According to Amidou (2014), since the emergence of digital marketing, Internet users, who are already consumers, have turned into journalists, videographers, photographers, and share their experiences to the point of developing an expertise. In brief, the digital world has become the preferred means for marketers to establish a direct relationship with their target.

\section{A Marketing Based On the Customization of the Offer}

Customized marketing consists of individualizing actions of promotion and communication according to the profile of each client. Customization can deal with the channel or the medium, the message or the offer. Customized marketing is theoretically more modest in its practice than "one-to-one" marketing because customization is often done at the level of the recipient's data and the offer may be common to the target or the segment.

In territorial marketing, Chamard (2014) explains that in the process of the creation of a direct link with the customer, customized territorial marketing is a powerful weapon to address the fierce competition. This territorial marketing takes the shape of tools such as RSS, applications, maps, research engines and customized offers of tracking systems (Chamard, 2015). It is a set of tools that allow direct and permanent contact with clients. This is easy and feasible nowadays with the development of mobile users and the instantaneity of customized communication with the client, which allows a direct relationship with the targeted individuals (Villimus, 2014).

Gollain (2014) completes the study and promotes the idea that marketers should place the customers at the heart of the territorial marketing approach and bring an offer that is both differentiated and customized at demand. Villemus (2014) adds that transactional marketing and relational marketing will no longer fit the need and will be replaced with a marketing that is intimate, personalized, sincere and interactive.

\section{A Viral Marketing}

Viral marketing is a technique that aims at promoting an offer through a persuasive message transmitted from a person to another. It is called viral as the offer is considered to spread out like a virus.

Chamard (2014) points out the benefits of viral marketing and stipulates that it is focused on leverage effects that try to organize the "virality" towards the entire set of the marketing mix elements. It is both a result of and a bedrock for affinitybased marketing and customized marketing. One of the most exemplary territories having experimented viral marketing is the Excellence branch "Lumière" (Light) in Lyon region, with the cluster Lumière considered as a textbook case in this field. Once again, the Internet and connected objects will help speed up this type of approaches. Gayet remarks that viral marketing will undoubtedly help create leverage.

On the other hand, this category of marketing allows, according to Villemus, going back to the etymologic meaning of the word "communicating" which is defined as "putting in common". This definition is the one retained by several researchers in the field of psychology, namely by Salomé (2003). In this sense, individuals are in a permanent exchange of advice and recommendations. They become first-level influencers and intervene in the process of decision making for potential clients. The customers are 
now empowered since, after the first purchase, they turn into consultants with the ability to anticipate the experience of others, in addition to becoming parties in the phrasing of marketing expectations. Thus, thanks to the network marketing and viral marketing, the traditional pattern of marketing communication from the 1950s (Attention, Interest, Desire and Action) is fundamentally shaken.

\section{A Customer Experience-Based Marketing}

Experiential marketing is a concept created by Halbrook and Hirschman in the Eighties and gets its basic concepts from hedonistic philosophy, customization, memory and emotion. It is meant to make the customers remember their experience and want to renew it. This marketing has been spread out since 1999 in the USA and in many European countries by Joseph Pine and Gim Gilmore through their book "the Experience Economy" (Harvard Business Review), with the key concept of progression of the economic value. The history of economy could hence be summed up with the help of the four stages of economic value progression:

- $\quad$ The stage of raw material economy where the essential know-how consists in farming and extracting merchandise from the earth;

- The stage of industrial economy, where the fundamental know-how consists in crafting manufactured goods in big quantities and thus largely standardized;

- The stage of the economy of services, whose first stake of sales is to provide a quality service. The sectors of Internet access and mobile telephony are revealing of the speed at which an offer of service becomes standardized;

- The stage of the "Experience Economy", which know-how is about bringing a real emotion and providing an unforgettable memory to the customer by integrating a strong dimension of customization.

It is worth noting that the set of the three elements (customization, emotion and memory) helps distinguish the concept of "experience" from that of "service" or "product". It should be mentioned that emotions have a great impact; they allow assigning values to the various options or product attributes (Eshui, Klijn and Braun, 2014).

Among the tools developed by experiential marketing, is sensorial marketing. In what follows, we will develop examples of territories and brands having opted for this experiential marketing and used sensorial marketing:

- Fragrant cleaners at the Regie Autonome des Transports Parisiens (olfactory)

- Decoration of tramway units at Montpellier (optic)

- Tasting of pasteis offered by the region of Lisbon (gustatory)

- Background music played in Abercrombie \& Fitch stores (acoustic)

- $\quad$ Grained surface of Vichy lozenges (tactile), (Batat and Frochot, 2014)

These factors help broaden the diverse elements involved in the decision making process to build conceptual marketing as developed by Patat and Frochot (2014).

Gayet concludes that marketing should "reenchant the act of purchasing by considering, in a certain way, that it is not the product that creates the experience but the experience that creates the product"; which sends a strong and direct message to territorial marketers.

\section{Towards a New Territorial Marketing}

\section{Delimitation of the concept of territorial identity}

Identity is usually a problematic, polemical, even explosive topic, because it is extremely connotative and can be easily "instrumentalized", both politically and ideologically.

At first sight, the process of territorial identification refers to the spatial dimension since territories can be identified according to the criterion of size 
(regional, municipal, etc.). For Di Meo (2006), identity is thus represented "with mechanisms linked with space". But not only this, the researcher geographer also mentions at a more global scale the reason why "differential and territorial" identities are supported by cultural, religious and landscape factors. Hence, the existence of a factory of identities sorted by a "hierarchical classification of affiliations" to the territory.

Consequently, territorial identity is a social phenomenon, resulting from relationships with others (Mead, 1963). It is a virtual entity to which people refer to explain who they are and through which they define themselves (Levi-Strauss, 1979). In territorial identity, it is the territory, as a spatial artefact holding cultural signs and endowed of significations, which fuels the construction of meaning, of subject and of community. Reference to a specific space builds awareness of a collective uniqueness. The social and cultural singularity is reciprocally sustained by the same space singularity that it helps produce. Thus, territorial identity is assimilated to the procedures of symbolization, of spatial integration of the founding structures of collective life: myths and history, as a core and as boundaries (Segaud, 1983, Bonnemaison, 2000).

The identity of the territory is then defined through a singularity that gives it the status of a proper object and a spatial object. As such, it falls first within an act of social categorization (Dubar, 1998), allowing distinguishing and differentiating in order to elaborate a future strategy of space.

We retain in our study the following definition: identity includes the acquired but also the constructed, it is an articulation between what the territory is today, what it was yesterday and what it wants to become tomorrow.

\section{An Identity Marketing}

In the ten new trends of territorial marketing expanded in this article, the aspects of this particular marketing lie on recent experiences and some territories call on several forms and various practices to shape their offer.

Nonetheless, practitioners and researchers are getting more aware of the importance of identity as a cornerstone for the development of these new trends.

In this perspective, identity is viewed, according to Gayet (2015), as a base underlying the meaning of the approach and on which stand elements as powerful as value and linkage. Nicolas Baygert (2014) thinks that identity is a set of signs expressing a collective effort (both private and public) and involving the active forces of a territory gathered around a common objective.

Along those lines, identity is perceived as a key pivot around which are constructed the strategy, the governance, the offer, the brand, the brand image of the territory as well as its communication. This identity has to be shared by a great majority of inhabitants, actors and stakeholders, which is not an easy task (Maynardier, 2011). Rochette (2012), for her own part, supports the idea that identity is a prerequisite to the creation and deployment of a brand. To demonstrate her position, she cites the example of territorial brands having encountered a great success: Bretagne in 2008, Auvergne in 2010 and Alsace in 2012. According to her, identity is one of the territory's resources that is singular, non-imitable and nonsubstitutable. However, the value attributed to this identity depends on the capacity of the decision-makers, the actors and the stakeholders to showcase it in front of consumers in search of that touch of authenticity.

On the other hand, since the individuals, when integrating a territory, project themselves and their future on it and see in it a place to achieve their projects, Maynardier (2011) raises another question, which is whether the experts and city managers, by evoking attachment to the territory, distinguish it clearly from the location potentiated for a project. Determination of the criteria of attachment to the territory and the elements defining identity is a major component in the

Yasmine ALAOUI and Rihab ABBA (2019), Journal of Marketing Research and Case Studies,

DOI: $10.5171 / 2019.944163$ 
strategy of competitiveness and territorial attractiveness, either endogenously or exogenously or both at the same time.

Meyronin (2015) confirms that identity has a central role in the strategy of attractiveness and adds that "no marketing strategy can succeed if separated from reality, and consequently here from what founds the identity of a territory". He also mentions, on one hand, the vital need of elected representatives and instances in charge of territorial marketing and attractiveness strategy to assert and/or reinvent this identity, and, on another hand, the necessity they have to foster, at the level of their inhabitants, a feeling of belonging to their territory.

By adopting identity as a base, this new trend advocates the fact that identity forms the reservoir to the territory's values, and allows the territory to federate stakeholders, to develop its brand on solid grounds and to design a squared offer for inhabitants who will act as ambassadors, as well, for tourists and investors.

To sum up, an identity-based marketing will aim at facilitating exchanges both on the internal and the external levels, at drawing from the territory's values and then at informing the choices for the other marketing trends developed above.

\section{Zoom on the Marketing Approach based on Territorial Identity}

The instances in charge of implementing the approach of territorial marketing must thoroughly prepare their strategies and commit to evaluate the action plan starting from the first year of implementation. Concurrently, they will call on specific control tools or techniques in a spirit of experience optimization. This could be done thanks to the interaction with the field feedbacks in the perspective of performance improvement for the following years.

The figure shown hereunder presents an overview of the steps followed in a territorial marketing approach. The one we are suggesting is divided into three main phases: a strategic phase, called "upstream phase", includes the determination of the relevant territory, the identification of stakeholders and the strategic diagnosis. The second phase is intermediary. This "transition phase" includes segmentation, targeting and positioning of the territory. The third phase, called "downstream phase", consists in outlining the territorial offer and breaking it down into a territorial mix marketing. This approach is initiated by the development of a marketing mindset and an identity profiling which is a key step throughout the approach and has to be preceded by the fostering of an endogenous territorial governance. 


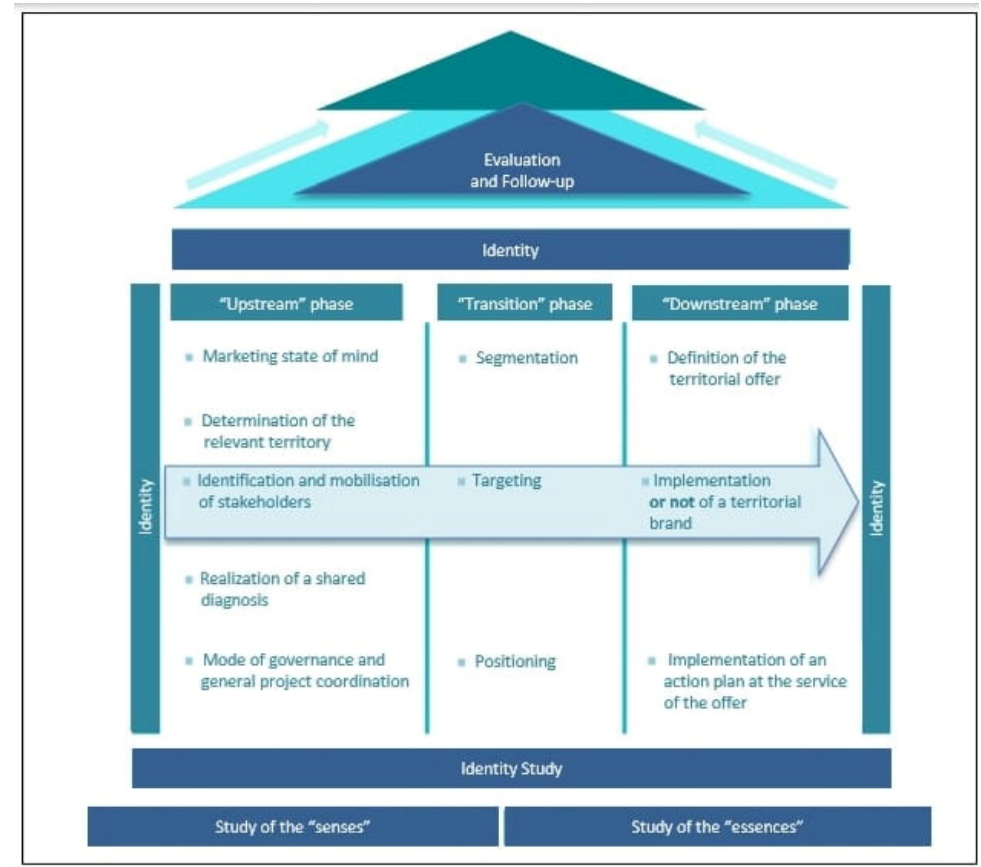

Fig. 1: Territorial Marketing approach

Yasmine ALAOUI and Rihab ABBA (2019), Journal of Marketing Research and Case Studies, DOI: $10.5171 / 2019.944163$ 


\section{Overview of the New Trends of Territorial Marketing}

Table 1 : The new trends of Territorial Marketing

\begin{tabular}{|c|c|c|c|c|}
\hline Trend & Main idea & Definition & Foundations & Examples \\
\hline \multirow{6}{*}{$\begin{array}{l}\text { Holistic } \\
\text { marketing or } \\
\text { integrated } \\
\text { Marketing }\end{array}$} & \multirow{6}{*}{$\begin{array}{l}\text { Based on territory } \\
\text { project }\end{array}$} & \multirow{6}{*}{$\begin{array}{l}\text { Consists in tackling all } \\
\text { functions and aspects } \\
\text { of territorial marketing: } \\
\text { its strategy, its } \\
\text { financing, its } \\
\text { positioning, its brand, } \\
\text { etc. }\end{array}$} & $\begin{array}{l}\text { - Integration of the TMA } \\
\text { (Territorial Marketing } \\
\text { Approach) within the } \\
\text { territory's project. }\end{array}$ & $\begin{array}{l}\text { «Barcelona Vision } \\
2020 »\end{array}$ \\
\hline & & & $\begin{array}{l}\text { - Integration of the TMA in } \\
\text { the process of operational } \\
\text { development. }\end{array}$ & $\begin{array}{l}\text { Saint Etienne } \ll 80 \\
\text { actions do boost } \\
\text { Stephanoise } \\
\text { attractiveness » }\end{array}$ \\
\hline & & & $\begin{array}{l}\text { - Development of a territorial } \\
\text { brand. }\end{array}$ & $\begin{array}{l}\text { «Amsterdam } \\
\text { Marketing » }\end{array}$ \\
\hline & & & $\begin{array}{l}\text { - Emergence of a willingness } \\
\text { to tune marketing } \\
\text { coordination with a function } \\
\text { of conductor, whose primary } \\
\text { mission is to optimize } \\
\text { marketing actions or tools, } \\
\text { and/or to mutualize } \\
\text { techniques and operations. }\end{array}$ & $\begin{array}{l}\text { Lyon / Colorado or } \\
\text { the Michigan / Berlin / } \\
\text { Brussels }\end{array}$ \\
\hline & & & \multirow{2}{*}{$\begin{array}{l}\text {-Developing a marketing } \\
\text { strategy based on a big vent } \\
\text { or a major facility. }\end{array}$} & $\begin{array}{l}\text { London (Olympic } \\
\text { Games). }\end{array}$ \\
\hline & & & & $\begin{array}{l}\text { Marseille (European } \\
\text { Capital of Culture) and } \\
\text { Brazil (Football World } \\
\text { Cup) }\end{array}$ \\
\hline \multirow{3}{*}{$\begin{array}{l}\text { Shared } \\
\text { Marketing }\end{array}$} & \multirow{3}{*}{$\begin{array}{l}\text { Formalising common } \\
\text { and shared values }\end{array}$} & \multirow{3}{*}{$\begin{array}{l}\text { There must be a } \\
\text { synergy between actors } \\
\text { as well as a porosity } \\
\text { between sectors to } \\
\text { allow optimisation and } \\
\text { mutualisation of } \\
\text { resources. }\end{array}$} & $\begin{array}{l}\text { - Animation of a stakeholders } \\
\text { network. }\end{array}$ & \multirow{3}{*}{ Bretagne region } \\
\hline & & & $\begin{array}{l}\text { - Stakeholders will naturally } \\
\text { stick to the values they have } \\
\text { participated in formulating. }\end{array}$ & \\
\hline & & & $\begin{array}{l}\text { - The inhabitants have a great } \\
\text { part of responsibility and } \\
\text { identity is a foundation for } \\
\text { these values. }\end{array}$ & \\
\hline $\begin{array}{l}\text { Citizen-based } \\
\text { Marketing }\end{array}$ & Involving the citizens & $\begin{array}{l}\text { Citizens have started } \\
\text { manifesting their } \\
\text { willingness to take part } \\
\text { in the development of } \\
\text { their territories }\end{array}$ & $\begin{array}{l}\text { - Today's citizens are } \\
\text { involved in the strategies of } \\
\text { attractiveness and territorial } \\
\text { marketing, through meetings } \\
\text { and Internet-based consulting }\end{array}$ & $\begin{array}{l}\text { Alsace region has } \\
\text { worked on its identity } \\
\text { and its territorial } \\
\text { attractiveness approach } \\
\text { with more than } 4200 \\
\text { residents thanks to its }\end{array}$ \\
\hline
\end{tabular}




\begin{tabular}{|c|c|c|c|c|}
\hline & & & $\begin{array}{l}\text { - Territorial marketing } \\
\text { doesn't aim at satisfying } \\
\text { tourists and investors alone, } \\
\text { but above all inhabitants. }\end{array}$ & $\begin{array}{l}\text { blog and to social } \\
\text { media. }\end{array}$ \\
\hline & & & $\begin{array}{l}\text { - Residents are both } \\
\text { participants and recipients }\end{array}$ & \\
\hline & & & $\begin{array}{l}\text { - Residents act as first } \\
\text { ambassadors for their } \\
\text { territory }\end{array}$ & \\
\hline \multirow[b]{2}{*}{$\begin{array}{l}\text { Marketing } \\
\text { based on hyper- } \\
\text { segmentation }\end{array}$} & \multirow[b]{2}{*}{$\begin{array}{l}\text { Suggesting a squared } \\
\text { offer to the customer. }\end{array}$} & \multirow{2}{*}{$\begin{array}{l}\text { The affinity-based } \\
\text { segmentation and } \\
\text { communicating with } \\
\text { the customers in an } \\
\text { adapted way gives } \\
\text { better results. }\end{array}$} & $\begin{array}{l}\text { - The territorial offer is more } \\
\text { and more segmented and } \\
\text { personalized. }\end{array}$ & $\begin{array}{l}\text { Esprit Picardie: } \\
\text { dividing a touristic } \\
\text { offer in romantic } \\
\text { week-end / family } \\
\text { stay, etc. }\end{array}$ \\
\hline & & & $\begin{array}{l}\text { - Participation of the } \\
\text { customers to the elaboration } \\
\text { of their own territorial offer } \\
\text { thanks to the digital tools }\end{array}$ & $\begin{array}{l}\text { Alsace : developing } \\
\text { affinity-based themes } \\
\text { gathering a great } \\
\text { number of individuals } \\
\text { and creating leverage: } \\
\text { « Christmas in } \\
\text { Alsace», « The Road } \\
\text { of Alsace wines », etc. }\end{array}$ \\
\hline \multirow[b]{2}{*}{$\begin{array}{l}\text { Excellence } \\
\text { Marketing }\end{array}$} & \multirow[b]{2}{*}{$\begin{array}{l}\text { Developing key } \\
\text { competencies }\end{array}$} & \multirow[b]{2}{*}{$\begin{array}{l}\text { Excellence is no longer } \\
\text { a choice, it has become } \\
\text { a sales factor }\end{array}$} & \multirow{2}{*}{$\begin{array}{l}\text { - Excellence and suggesting } \\
\text { performing methods and } \\
\text { solutions require to dare do } \\
\text { things differently, to break } \\
\text { with the existing and to foster } \\
\text { innovation. }\end{array}$} & $\begin{array}{l}\text { Excellence can be } \\
\text { found in clusters, } \\
\text { governance, labels, } \\
\text { sustainability, } \\
\text { innovation, } \\
\end{array}$ \\
\hline & & & & $\begin{array}{l}\text { performing } \\
\text { ecosystems, } \\
\text { collaborative } \\
\text { economy, territorial } \\
\text { brand, smart city and } \\
\text { real-time Client } \\
\text { Relationship } \\
\text { Management. }\end{array}$ \\
\hline \multirow{5}{*}{$\begin{array}{l}\text { Creative } \\
\text { Marketing }\end{array}$} & \multirow{5}{*}{$\begin{array}{l}\text { Innovating for } \\
\text { survival }\end{array}$} & \multirow{5}{*}{$\begin{array}{l}\text { The capacity to } \\
\text { produce new and } \\
\text { adapted ideas in the } \\
\text { public field is not } \\
\text { generated } \\
\text { spontaneously, it has to } \\
\text { be managed and } \\
\text { supervised. }\end{array}$} & $\begin{array}{l}\text { - Creativity is based on three } \\
\text { pillars : }\end{array}$ & \multirow{5}{*}{$\begin{array}{l}\text { - Development of the } \\
\text { strategy « Blue } \\
\text { Ocean ». } \\
\text { - UNESCO created in } \\
2004 \text { a network } \\
\text { dedicated to the } \\
\text { creative cities in order } \\
\text { to build an alliance } \\
\text { likely to exploit the } \\
\text { creative, social and } \\
\text { economic potential of } \\
\text { local communities and } \\
\text { promote it. }\end{array}$} \\
\hline & & & $\begin{array}{l}* \text { Climate : refers to an } \\
\text { atmosphere of trust-building } \\
\text { and autonomy }\end{array}$ & \\
\hline & & & $\begin{array}{l}\text { * Competences : individual } \\
\text { and collective ; }\end{array}$ & \\
\hline & & & $\begin{array}{l}\text { * Processes : central element } \\
\text { that grants and fosters } \\
\text { participation of the many }\end{array}$ & \\
\hline & & & $\begin{array}{l}* \text { Innovation and creativity } \\
\text { are essential at all levels of } \\
\text { the TMA }\end{array}$ & \\
\hline
\end{tabular}




\begin{tabular}{|c|c|c|c|c|}
\hline \multirow[b]{2}{*}{$\begin{array}{l}\text { Digital } \\
\text { Marketing }\end{array}$} & \multirow[b]{2}{*}{$\begin{array}{l}\text { Getting closer to the } \\
\text { target }\end{array}$} & \multirow[b]{2}{*}{$\begin{array}{l}\text { The preferred means } \\
\text { for marketers that } \\
\text { allows them to } \\
\text { establish a direct } \\
\text { relationship with their } \\
\text { target. }\end{array}$} & $\begin{array}{l}\text { - Refers to the set of digital } \\
\text { methods and practices. }\end{array}$ & \multirow[b]{2}{*}{$\begin{array}{l}\text { Nowadays, the } \\
\text { majority of territories } \\
\text { uses digital marketing } \\
\text { in their TMA. }\end{array}$} \\
\hline & & & $\begin{array}{l}\text {-Since the rise of digital } \\
\text { marketing, Internet users } \\
\text { have become consumers as } \\
\text { well as journalists, } \\
\text { videographers, } \\
\text { photographers; they share } \\
\text { their experiences to the point } \\
\text { of developing an expertise. }\end{array}$ & \\
\hline $\begin{array}{l}\text { Customization } \\
\text { Marketing }\end{array}$ & $\begin{array}{l}\text { Individualizing the } \\
\text { communication }\end{array}$ & $\begin{array}{l}\text { Adapts the actions of } \\
\text { promotion and } \\
\text { communication to the } \\
\text { profile of each client }\end{array}$ & $\begin{array}{l}\text { Places the clients at the heart } \\
\text { of the approach in order to } \\
\text { give them an offer both } \\
\text { differentiated and } \\
\text { personalized }\end{array}$ & $\begin{array}{l}\text { Uses tools that allow } \\
\text { direct and permanent } \\
\text { contact with the } \\
\text { customers, such as } \\
\text { RSS, applications, } \\
\text { maps and research } \\
\text { engines }\end{array}$ \\
\hline \multirow[b]{2}{*}{ Viral Marketing } & \multirow{2}{*}{$\begin{array}{l}\text { Transforming the } \\
\text { client into a consultant }\end{array}$} & \multirow{2}{*}{$\begin{array}{l}\text { Allows the creation of } \\
\text { leverage. }\end{array}$} & $\begin{array}{l}\text {-Aims at promoting an offer } \\
\text { through a persuasive message } \\
\text { that would be transmitted } \\
\text { from a person to another. } \\
\text { Called viral because the offer } \\
\text { spreads like a virus. }\end{array}$ & \multirow{2}{*}{$\begin{array}{l}\text { The Excellence Branch } \\
\text { «Lumière » of Lyon } \\
\text { region with the cluster } \\
\text { Lumière (considered } \\
\text { as a textbook case in } \\
\text { the field). }\end{array}$} \\
\hline & & & $\begin{array}{l}\text { - Based on the leverage } \\
\text { effects that try to organise the } \\
\text { « virality » towards the set of } \\
\text { marketing mix components. } \\
\text { - Both a result and a bedrock } \\
\text { for affinity-based marketing } \\
\text { and customized marketing. }\end{array}$ & \\
\hline \multirow{5}{*}{$\begin{array}{l}\text { Experiential } \\
\text { Marketing }\end{array}$} & \multirow{5}{*}{$\begin{array}{l}\text { Encouraging the } \\
\text { targets to come back } \\
\text { by triggering their } \\
\text { emotions }\end{array}$} & \multirow{5}{*}{$\begin{array}{l}\text { Is based on } \\
\text { personalization, } \\
\text { emotion and memory. }\end{array}$} & \multirow{5}{*}{$\begin{array}{l}\text { - Re-enchants the act of } \\
\text { purchasing by considering, in } \\
\text { a certain way, that it is not } \\
\text { the product that creates the } \\
\text { experience but the experience } \\
\text { that creates the product. }\end{array}$} & $\begin{array}{l}\text { Fragrant cleaners of } \\
\text { RATP (olfactory) }\end{array}$ \\
\hline & & & & $\begin{array}{l}\text { Decoration of the } \\
\text { tramway units at } \\
\text { Montpellier (optic) }\end{array}$ \\
\hline & & & & $\begin{array}{l}\text { Tasting of Pasteis } \\
\text { offered by the region } \\
\text { of Lisbon (gustatory) }\end{array}$ \\
\hline & & & & $\begin{array}{l}\text { Music played in } \\
\text { Abercrombie \& Fitch } \\
\text { (acoustic) }\end{array}$ \\
\hline & & & & $\begin{array}{l}\text { Grained surface of } \\
\text { Vichy lozenges } \\
\text { (tactile) }\end{array}$ \\
\hline $\begin{array}{l}\text { Identity } \\
\text { Marketing }\end{array}$ & $\begin{array}{l}\text { Considering identity } \\
\text { as a base for all the } \\
\text { previous trends. }\end{array}$ & $\begin{array}{l}\text { Identity is a reservoir } \\
\text { for the territory values. }\end{array}$ & $\begin{array}{l}\text { - Identity is perceived as a } \\
\text { key pivot around which are } \\
\text { built the strategy, } \\
\text { governance, offer, brand, } \\
\text { brand image and } \\
\text { communication of the } \\
\text { territory. }\end{array}$ & $\begin{array}{l}\text { Bretagne region in } \\
2008\end{array}$ \\
\hline
\end{tabular}




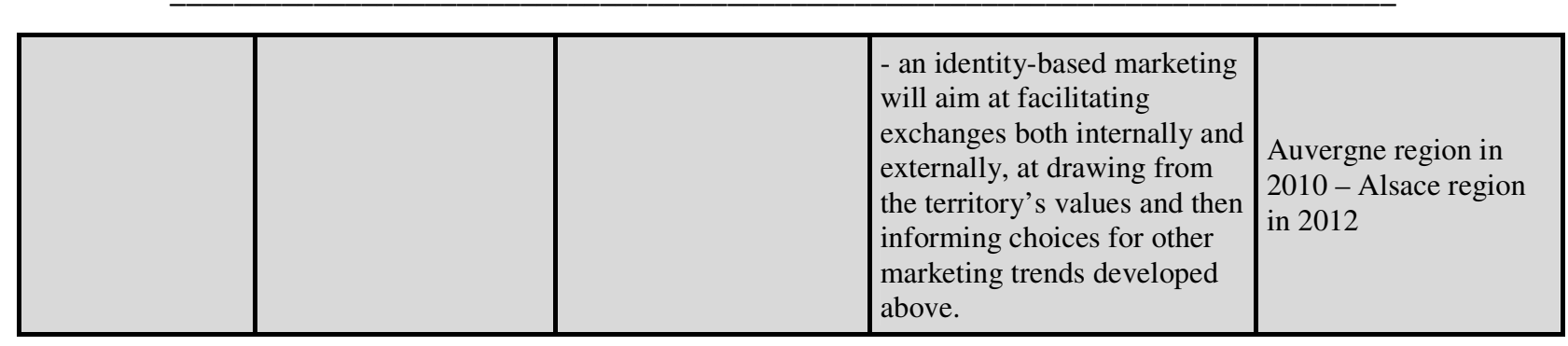

\section{Conclusion}

Identity marketing allows highlighting the universal values of the territory; the ones that define what it is today and what it wants to become, while respecting what it was. Those strong territory values form the cement to all the new trends of territorial marketing. They use digital marketing as a transversal tool, since it contributes to the proper application of these trends and helps involve the citizens, thanks to the development of a "bottom-up" strategy, throughout the approach of a territorial marketing: from the elaboration of the identity profile to the design of the offer. That approach must be imbued with innovative and creative spirit. As such, territorial marketing will focus on the complementarity of the new trends. It will represent, for all stakeholders, "the Good, the Beautiful and the Righteous", as Plato put it, while insisting on the role of identity as a foundation for all territorial marketing considerations, which will be revolutionary in the practice of territorial marketing.

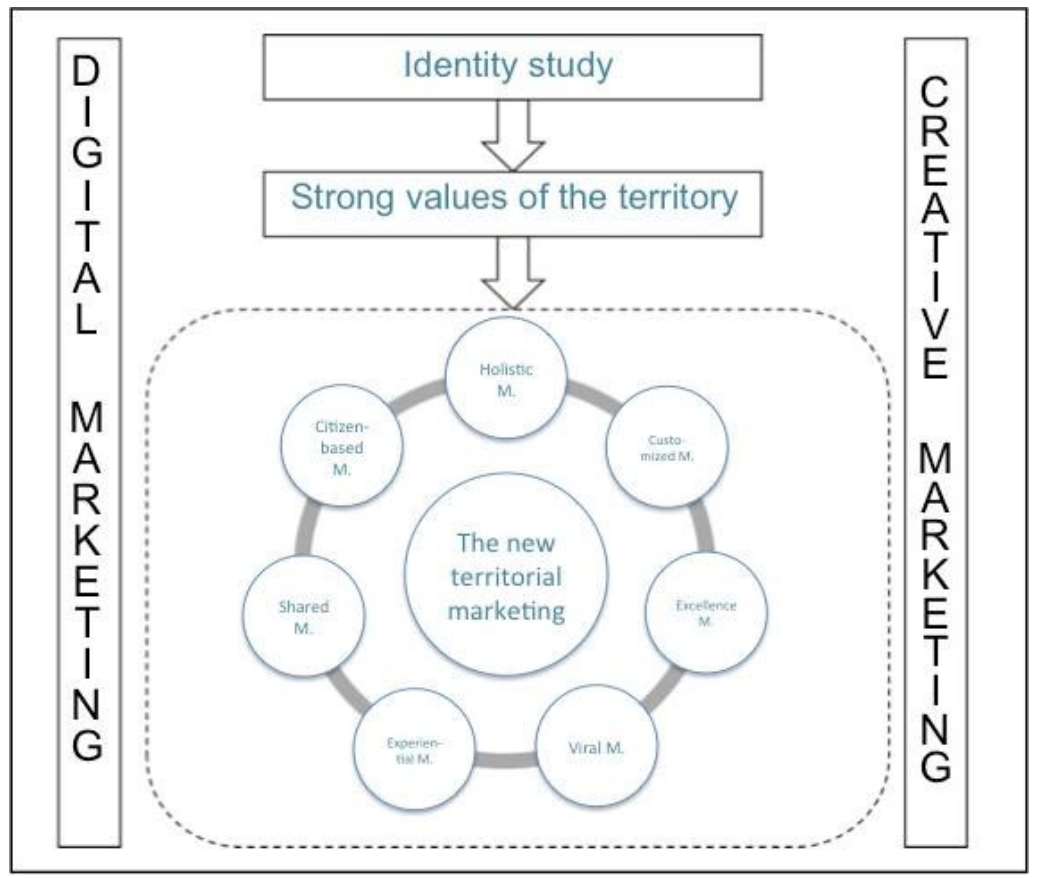

Fig. 2: The new territorial marketing 
In the end, we insist that identity should be at the lead and at the beginning of every strategy and decision related to the territory » (Alaoui, Abakouy, 2017).

Drawing from its identity would thus allow the territory to stand out from its competitors by showcasing its values and cultivating its difference thanks to its authenticity. It would also help create a sustainable link with its inhabitants and turn them into ambassadors, give a security guaranty for investors since identity charts a historic path and highlights its future projects. Lastly, identity studies would form a promise of authenticity for the tourists attracted by the essence of the territories they visit. A question arises and remains in all territories: How can they strike a balance between their identity appeals and the increasing complexity of globalisation and which mode of governance could facilitate this mindset?

\section{References}

1. Abakouy, M. \& Alaoui, Y. (2015), "L'identité de la Sociologie aux Sciences Sociales », ACMS

2. Abakouy, M. Laghzaoui, F (2015), "Pratiques du Marketing Territorial au Maroc: Etude de l'Expérience de la Ville de Tanger », Revista de Estudios Fronterizos Del Estrecho de Gibraltar.

3. Abakouy, M., Alaoui, Y. (2015). «Modélisation de la Démarche Marketing Territorial », Revue de Management, Vol (03), pp. 42-60.

4. Alaux C. (2012), « Measuring the Brand Image of a City" Colloque International EGPA Bergen (Norvège), Public and non for profit marketing Study group, 5-8 Septembre.

5. Alaux C. (2014), « Place Marketing Relationships : In Need of a New Strategy », Colloque International EGPA Speyer (Allemagne), Public and non for profit marketing Study group, 5-8 Septembre 2014.

6. Alaux C. (2015), « Le Marketing Territorial Relationnel: une Approche Adaptée à l'Image de Marque des Petites Villes », dans Bourdeau-Lepage L. et Gollain
V. Coord., « Attractivité et Compétitivité des Territoires: Théories et Pratiques», CNER.

7. Amidou L., (2014), «Marketing des Réseaux Sociaux », 2ème édition, Micro Application.

8. Batat W., Frochot I, (2014), « Marketing Expérientiel : Comment Concevoir et Stimuler l'Expérience Client », Dunod.

9. Baygert N., (2014/3), «Le Nouveau Branding Wallon », Outre-terre ( $\left.{ }^{\circ} 40\right)$, P.156-165

10. Bonnemaison J. (1995), « Le Territoire, Nouveau Paradigme de la Géographie Humaine ? », Acte du colloque «Le Territoire, Lien ou Frontière ? », 2-4 octobre, Paris-Sorbonne, pp.1-4.

11. Braun, E., Eshuis, J., \& Klijn, E-H. (2014). "The Effectiveness of Place Brand Communication ». Cities, 41, 64-70.

12. Braun, E., Kavaratzis, M., \& Zenker, S.. (2013). « My City - My Brand: The Different Roles of Residents in Place Branding». Journal of Place Management and Development, 6(1), 18-28. doi: 10.1108 /17538331311306087

13. Braun, E. (2008). " City Marketing: Towards An Integrated Approach ». (Ph.D. thesis), Erasmus

14. Brenner, N. (2004). " New State Spaces: Urban Governance and the Rescaling of Statehood » : OUP Oxford.

15. Chamard C. \& al. (2014), «Le Marketing Territorial - Comment Développer l'Attractivité et l'Hospitalité des Territoires », De Boeck, 203 p.

16. Di Meo G., (1998), «Extrait de Géographie Sociale et Territoire ». Editions Nathan

17. Di Meo, G. (2009), «Le Rapport Identité/Espace. Éléments Conceptuels et Epistémologiques ", dans Grandjean P., Construction identitaire et espace, L'Harmattan, Paris, pp. 19-39,.

18. Dubar C. (1991) «La Socialisation ; Construction des Identités Sociales et Professionnelles », A. Colin, Paris (3e éd. 2000).

19. Eshuis, J., \& Klijn, E., (2012). «Branding in Governance and Public Management »: Routledge.

20. Eshuis, J., Klijn, E.H., \& Braun, E. (2014a). « Marketing territorial et Participation Citoyenne: le Branding, un Moyen de faire face à la Dimension 
Emotionnelle de l'Elaboration des Politiques? 》 Revue Internationale des Sciences Administratives, 80(1), 153-174.

21. Garcia M., De Peganow N., (2012), «Innovation Participative: Remettre l'Humain au Cœur de l'Entreprise ", Scrineo, pp.77-81.

22. Gayet J., (2016), «Pratique 31 / Développement d'Approches «Place Making » et Collaboratives du Marketing Territorial », dans Place Marketing Trend, Chaire Attractivité et Nouveau Marketing Territorial, pp. 309-313.

23. Gayet.J. (2014) «Forum, Place Marketing, Attractivité, C., et Territorial, Nouveau Marketing Territorial». Place Marketing Trend, 1-282.

24. Holbrook M. \& Hirschman E. (1982), "The Experiential Aspects of Consumption: Consumer Fantasies, Feelings and Fun", Journal of Consumer Research, 9, 132-140.

25. Levi-Strauss C. (1979), «Résumé des cours et travaux (1978-1979)», Annuaire du Collège de France

26. Maynadier,B. (2011), « Marketing de la ville : entre les identités, des communautés de projet », Cahiers ISERAM, pp.1-16

27. Mead, G. H. (1963). «L'Esprit, le Soi et la Société », trad. PUF, Paris.

28. Meyronin B., (2015), «Marketing territorial - Enjeux et pratiques », Magnard - Vuibert, 3ème édition, 236 p.

29. Meyronin, B (2006), «Marketing des Services Publics et Marketing des Territoires : Vers une Dynamique de RéEnchantement », Atelier de L'association International De Management Stratégique, Stratégie, Espaces et Territoires.
30. Meyronin, B. (2008), « Marketing des Services Publics et Marketing Territorial: Vers une Dynamique de Ré enchantement? », Economies et Sociétés, série Economie et gestion des services, EGS, $\mathrm{n}^{\circ} 9,2$.

31. Meyronin, B. (2012), «Marketing territorial. Enjeux et pratique ». Paris : Vuibert. 2ème édition.

32. Meyronin C. (2015), «La Marque Publique entre Nouvelles Pratiques et Valeurs Publiques», Revue Internationale de Sciences Administratives, Vol. 81(2), p 326345, (http://ras.sagepub.com/) (www.cairn.info).

33. Rochette C. (2015), «The Public Brand Between New Practices and Public Values ». International Review of Administrative Sciences, Volume 81 (2), p 326-345,

34. Rochette C., Cassiere F, Lambey C., Lagrange S (2016), "Réinventer l'Agence Bancaire de Demain : Mise en CEuvre d'Un Processus d'Innovation Collaborative", Revue Française de Marketing, ${ }^{\circ} 259$, p. 101-119.

35. Rochette C., Lebrument C., Fenies P., (2016), « Identification des Enjeux pour les Parties Prenantes et les Acteurs Engagés dans la Construction d'une Marque Région ", Revue Gestion et Management Public, vol 4, n³, avril-mai, p. 91-108

36. Salome J., (2003), « Pour ne plus Vivre sur la Planète Taire », Albin Michel, pp. 303-304.

37. Segaud M., Levy P. (1998), « Anthropologie de l'espace ». Paris : Centre Pompidou. 